\title{
Risk Sharing Agreement: Sebuah Ide Awal Mengenai Bentuk Alternatif Pendanaan Pemulihan Kerusakan Lahan Gambut Akibat Kebakaran Hutan dan/atau Lahan di Indonesia ${ }^{1}$
}

\author{
Savitri Nur Setyorini ${ }^{2}$ dan Emir Falah Azhari ${ }^{3}$
}

\begin{abstract}
Abstrak
Kebakaran hutan dan/atau lahan gambut di Indonesia telah menyebabkan pencemaran dan perusakan lingkungan hidup yang cukup masif dan memerlukan pemulihan agar lingkungan hidup dapat berfungsi sebagaimana mestinya. Namun, hal ini tidak mudah untuk dilakukan dikarenakan sampai sekarang penghimpunan dana pemulihan lingkungan hidup masih sangat bergantung pada pertanggungjawaban perdata, khususnya melalui proses pengadilan. Terlebih lagi, dana tersebut sulit untuk terkumpul karena jumlahnya yang besar dan proses pengadilan yang memakan waktu lama. Oleh karena itu, artikel ini hendak menganalisis perihal alternatif pendanaan pemulihan lahan gambut yang rusak akibat kebakaan hutan dan/atau lahan melalui sistem risk sharing agreement. Metode penelitian yang digunakan pada tulisan ini adalah yuridis-normatif. Hasil penelitian menunjukkan bahwa risk sharing agreement dapat menjadi alternatif untuk mendanai pemulihan, dengan mekanisme pembiayaan melalui sistem pool antara pelaku usaha, yang pembayaran kontribusinya dapat dilakukan secara ex-ante maupun ex-post, dimana pemantauan bersama antara anggotanya dapat meminimalisasi terjadinya risiko kebakaran hutan dan/atau lahan gambut. Kata kunci: hutan, lahan gambut, kebakaran, dana pemulihan lingkungan hidup, risk sharing agreement
\end{abstract}

\section{Abstract}

Forest and/or peatland fires in Indonesia have done massive environmental damage and require restoration on the burned areas to function properly. Unfortunately, the restorations are difficult to be done since the environmental restoration fund depends on civil liability, mainly through the litigation process. Moreover, the fund is difficult to be collected since it consists

${ }^{1}$ Tulisan ini merupakan pengembangan dari tugas akhir Emir Falah Azhari dengan judul "Penerapan Risk Sharing Agreement sebagai Sistem Pendanaan Pemulihan Lingkungan Hidup pada Lahan Gambut di Indonesia" pada tahun 2019. Adapun tugas akhir maupun naskah ringkas dari tugas akhir tersebut belum pernah dipublikasikan, termasuk oleh Perpustakaan Universitas Indonesia.

2 Savitri Nur Setyorini memperoleh gelar Sarjana Hukum (S.H.) pada tahun 2013 dan Magister Hukum (M.H.) pada tahun 2016 dari Fakultas Hukum Universitas Indonesia. Saat ini menjadi Staf Pengajar Hukum Lingkungan dan Sumber Daya Alam di Fakultas Hukum Universitas Indonesia. Korespondensi: ssetyorini704@gmail.com

${ }^{3}$ Emir Falah Azhari merupakan alumni Fakultas Hukum Universitas Indonesia dan memperoleh gelar Sarjana Hukum (S.H.) pada tahun 2019. Korespondensi: emirfalah@gmail.com 
Risk Sharing Agreement: Sebuah Ide Awal Mengenai Bentuk Alternatif Pendanaan Pemulihan Kerusakan Lahan Gambut Akibat Kebakaran Hutan dan/atau Lahan di Indonesia

of a large amount of money and a long-term litigation process. Therefore, this article aims to analyze an alternative mechanism to fund the restoration of damaged peatland through risk sharing agreement. This article uses the normative-juridical method. This article shows that risk sharing agreement can be an alternative to fund the restoration, through pool system mechanism between corporations, which contribution will be collected through ex-ante or ex-post payment, where mutual monitoring between members can minimize the risk of forest and/or peatland fires.

Keywords: forest, peatland, fires, environmental restoration fund, risk sharing agreement

\section{Pendahuluan}

Berdasarkan data Direktorat Jenderal Planologi Kehutanan dan Tata Lingkungan Kementerian Lingkungan Hidup dan Kehutanan Republik Indonesia pada tahun 2017, luas hutan Indonesia adalah sekitar 93.600.000 ha. ${ }^{4}$ Selain itu, Indonesia merupakan pemilik lahan gambut terluas keempat di dunia, ${ }^{5}$ dengan total luas sekitar 24,136,669 ha ${ }^{6}$ atau sama dengan 10,8\% dari luas daratannya. ${ }^{7}$ Luasnya lahan gambut yang dimiliki oleh Indonesia merupakan hal yang sangat istimewa karena lahan gambut sangat berguna untuk menjaga dan memelihara keseimbangan lingkungan, khusus- nya sebagai reservoir air dan penyimpan karbon. ${ }^{8}$ Sebagai reservoir air, lahan gambut memiliki kemampuan untuk menahan daya air yang tinggi sehingga berfungsi sebagai penyangga hidrologi air lingkungan sekelilingnya. Selain itu, fungsi lahan gambut sebagai penyimpan karbon sangat berguna untuk menjaga keseimbangan gas rumah kaca. ${ }^{9}$

Saat ini, hutan dan lahan gambut Indonesia disebut sedang mengalami masa krisis karena masalah kebakaran hutan dan lahan gambut. Berdasarkan data Kementerian Lingkungan Hidup dan Kehutanan, sejak tahun 2013 hingga 2018 kebakaran hutan dan lahan di In-

\footnotetext{
${ }^{4}$ Kementerian Lingkungan Hidup dan Kehutanan (1), "Pencegahan Karhutla Berhasil Tekan Angka Deforestasi," http://www.menlhk.go.id/siaran-81-pencegahan-karhutla-berhasil-tekan-angka-deforestasi.html, diakses 16 Oktober 2018.

${ }^{5}$ Indonesia menempati urutan keempat setelah Kanada (170.000.000 ha), Rusia (150.000.000 ha), dan Amerika Serikat (40.000.000 ha). Lihat: Badan Restorasi Gambut, Rencana Strategis Badan Restorasi Gambut 2016 - 2020 (Jakarta: Badan Restorasi Gambut, 2016), hlm. 4.

${ }^{6}$ Kementerian Lingkungan Hidup dan Kehutanan (2), The State of Indonesia's Forests 2018 (Jakarta: Kementerian Lingkungan Hidup dan kehutanan Republik Indonesia, 2018), hlm. 71.

${ }^{7}$ Wahyunto, et. al., Sebaran Gambut dan Kandungan Karbon di Sumatera dan Kalimantan 2004 (Bogor: Wetlands International - Indonesia Programme, 2005), hlm. 1.

${ }^{8}$ Badan Restorasi Gambut, Op. Cit., hlm. 1.

${ }^{9}$ Ibid., hlm. 14.
} 
donesia telah mencapai angka 366.978,37 ha, ${ }^{10}$ dengan luas area kebakaran hutan dan lahan yang bervariasi setiap tahunnya. Pada tahun 2015, area kebakaran hutan dan lahan mencapai angka tertinggi, yakni 2.610.600,44 ha. ${ }^{11}$ Sementara itu, jumlah total luas lahan gambut yang rusak telah mencapai angka 23.949.527 ha dengan variasi kerusakan yang beragam, ${ }^{12}$ dimana hal tersebut belum termasuk data tahun 2019 yang menunjukkan terdapat 1.592.010,00 ha lahan terbakar, dengan Provinsi Sumatera Selatan menempati peringkat pertama lahan terbakar terluas, yakni seluas 328.457,00 ha. ${ }^{13}$

Langkah preventif untuk mencegah terjadinya kebakaran hutan dan lahan telah banyak dilakukan, namun langkah pemulihan yang dilakukan masih cukup minim. Salah satu hambatan dalam melakukan pemulihan lahan bekas terbakar adalah kurangnya dana yang terkumpul untuk dialokasikan pada pemulihan. Dalam Pasal 42 dan 43 Undang-Undang
Nomor 32 Tahun 2009 tentang Perlindungan dan Pengelolaan Lingkungan Hidup (selanjutnya disebut UUPPLH) telah disinggung perihal pendanaan lingkungan hidup yang digunakan untuk pelestarian fungsi lingkungan hidup. ${ }^{14}$ Kemudian, diterbitkan Peraturan Pemerintah Nomor 46 Tahun 2017 tentang Instrumen Ekonomi Lingkungan Hidup (selanjutnya disebut PP Instrumen Ekonomi) dan Peraturan Presiden Nomor 77 Tahun 2018 tentang Pengelolaan Dana Lingkungan Hidup (selanjutnya disebut Perpres Pengelolaan Dana Lingkungan Hidup) sebagai peraturan pelaksana dari Pasal 42 dan 43 UUPPLH. Selain itu, pendanaan lingkungan hidup juga didapatkan dari penyelesaian sengketa di dalam dan di luar pengadilan, serta melalui pemberian sanksi administratif.

Namun, hingga saat ini mekanisme kompensasi dan pemulihan lingkungan hidup di Indonesia masih sangat bergantung pada sistem pertanggungjawaban

\footnotetext{
${ }^{10}$ Kementerian Lingkungan Hidup dan Kehutanan (3), "Rekapitulasi Luas Kebakaran Hutan dan Lahan (Ha) per Provinsi di Tahun 2013 - 2018," http://sipongi.menlhk.go.id/hotspot/luas_kebakaran, diakses 28 Februari 2019.

${ }^{11}$ Tahun 2013 menjadi tahun terendah terjadinya kebakaran hutan dan lahan, yaitu pada angka 4.918,74 ha. Lihat: Ibid.

${ }^{12}$ Kementerian Lingkungan Hidup dan Kehutanan (2), Op. Cit., hlm. 71.

${ }^{13}$ Kementerian Lingkungan Hidup dan Kehutanan (4), «Rekapitulasi Luas Kebakaran Hutan dan Lahan (Ha) Per Provinsi Di Indonesia Tahun 2014-2019,» http://sipongi.menlhk.go.id/hotspot/luas_ kebakaran diakses pada 9 Maret 2020.

${ }^{14}$ Dana-dana ini terdiri dari yang terdiri dari dana jaminan pemulihan lingkungan hidup, dana penanggulangan pencemaran dan/atau kerusakan dan pemulihan lingkungan hidup, dan dana amanah/ bantuan konservasi. Lihat: Indonesia (1), Undang-Undang tentang Perlindungan dan Pemulihan Lingkungan Hidup, UU Nomor 32 Tahun 2009, LN Nomor 140 Tahun 2009, TLN Nomor 5059, Ps. 42 ayat (1) dan (2).
} 
Risk Sharing Agreement: Sebuah Ide Awal Mengenai Bentuk Alternatif Pendanaan Pemulihan Kerusakan Lahan Gambut Akibat Kebakaran Hutan dan/atau Lahan di Indonesia

perdata yang putusannya belum dapat dieksekusi. ${ }^{15}$ Selain itu, peraturan pelaksanaan mengenai dana lingkungan, yakni Perpres Pengelolaan Dana Lingkungan Hidup, belum dapat dilaksanakan. Terlebih lagi, asuransi pihak ketiga atas kerusakan lingkungan juga hanya diwajibkan pada sejumlah kecil kegiatan saja. ${ }^{16}$ Oleh karena itu, diperlukan suatu alternatif yang sekiranya dapat digunakan untuk mengakomodasi pendanaan untuk pemulihan lahan bekas terbakar tersebut, yakni melalui risk sharing agreement. Risk sharing agreement merupakan mekanisme pembiayaan yang dilakukan melalui sistem pool antara pelaku usaha yang pembayaran kontribusinya dapat dilakukan secara ex-ante maupun ex-post, dimana pemantauan bersama antara anggotanya dapat meminimalisasi terjadinya risiko kebakaran hutan dan/atau lahan gambut.

Oleh karena itu, artikel ini akan membahas perihal risk sharing agree- ment sebagai alternatif sistem pendanaan lingkungan yang dapat digunakan dalam rangka pemulihan lahan gambut yang terbakar atau lahan bekas terbakar. Pada Bagian II artikel ini, akan dibahas mengenai sistem pendanaan untuk pemulihan lingkungan hidup, kemudian pada Bagian III akan dibahas mengenai konsep dan penerapan risk sharing agreement sebagai alternatif sistem pendanaan pemulihan lahan gambut yang terbakar. Terakhir, bagian IV berisikan penutup.

\section{Sistem Pendanaan untuk Pemu- lihan Lingkungan Hidup}

\section{A. Pendanaan Pemulihan Ling- kungan Hidup}

UUPPLH sebagai payung hukum perlindungan dan pengelolaan lingkungan, telah mengatur tiga macam sistem kompensasi lingkungan hidup, yakni melalui pendanaan lingkungan hidup, penyelesaian sengketa lingkungan hidup, baik di dalam maupun di luar

${ }^{15}$ Sejak tahun 2015, Kementerian Lingkungan Hidup dan Kehutanan telah melakukan berbagai macam penegakan hukum terhadap pelaku kebakaran hutan dan lahan. Setidaknya terdapat sebanyak 171 sanksi administrasi, 11 gugatan perdata, dan 510 kasus pidana. Adapun sebanyak delapan gugatan perdata diantaranya telah diputus terbukti kegiatannya telah menyebabkan kebakaran hutan dan lahan serta lahan gambut, dan telah menyebabkan kerugian ekologis, sehingga para tergugat diminta untuk melakukan pemulihan lingkungan hidup dengan total biaya sebesar Rp1.816.705.990.100,00. Namun, dana tersebut belum dapat terkumpul karena putusan tersebut belum dieksekusi, sehingga belum ada tindakan pemulihan pada lahan bekas terbakar pada area konsesi sebagai bagian dari eksekusi putusan. Lihat: Indonesian Center for Environmental Law (1), Catatan Awal Tahun 2019 Indonesian Center for Environmental Law: Narasi yang Hilang dalam Proyeksi Kebijakan Lingkungan Hidup Capres-Cawapres (Jakarta: Indonesian Center for Environmental Law, 2019), hlm. 3 - 4.

${ }^{16}$ Andri G. Wibisana (1), Penegakan Hukum Lingkungan Melalui Pertanggungjawaban Perdata, ed. 1, cet. 1. (Depok: Badan Penerbit Fakultas Hukum Universitas Indonesia, 2017), hlm. 237. 
pengadilan, ${ }^{17}$ dan melalui penegakan sanksi administratif. ${ }^{18}$ Pendanaan lingkungan hidup merupakan suatu sistem dan mekanisme pengelolaan dana yang digunakan bagi pembiayaan upaya perlindungan dan pengelolaan lingkungan hidup..$^{19}$ Pendanaan lingkungan hidup meliputi dana jaminan pemulihan lingkungan hidup, dana penanggulangan pencemaran dan/atau kerusakan dan pemulihan lingkungan hidup, dan dana amanah/bantuan konservasi..$^{20}$ Pada bagian ini, pembahasan akan difokuskan pada dana terkait pemulihan lingkungan hidup.

Dana jaminan pemulihan lingkungan hidup digunakan untuk melaksanakan penanggulangan keadaan darurat lingkungan hidup di wilayah usaha dan/atau kegiatan yang disebabkan oleh usaha dan/atau kegiatannya dan pemu- lihan lingkungan hidup pasca operasi di wilayah usaha dan/atau kegiatan yang disebabkan oleh usaha dan/atau kegiatannya. ${ }^{21}$ Dalam PP Instrumen Ekonomi, tidak disebutkan pihak mana yang perlu menyediakan dana jaminan lingkungan hidup. Namun berdasarkan Pasal 55 ayat (1) UUPPLH, disebutkan bahwa yang wajib menyediakan dana untuk pemulihan fungsi lingkungan hidup adalah semua pemilik izin lingkungan. ${ }^{22}$ Dana ini dapat digunakan untuk melakukan penanggulangan dan pemulihan lingkungan hidup yang disebabkan oleh suatu usaha. ${ }^{23}$ Sementara dalam melaksanakan penanggulangan dan pemulihan lingkungan hidup, dana dapat disediakan dalam bentuk deposito berjangka, tabungan bersama, bank garansi, polis asuransi, dan/atau lainnya sesuai dengan peraturan perundang-undangan. ${ }^{24}$

${ }^{17}$ Dalam hal ini, tindakan pemulihan bukanlah satu-satunya implikasi dari penyelesaian sengketa, namun terdapat juga implikasi berupa pemberian ganti kerugian. Dana pemulihan lingkungan hidup sendiri sejatinya tidak selalu melekat pada penyelesaian sengketa, baik di dalam maupun di luar pengadilan, melainkan dapat pula berasal dari dana yang dijaminkan (dana jaminan pemulihan) sebagaimana diatur dalam Pasal 43 ayat (2) huruf a maupun Pasal 55 UUPPLH, yang selanjutnya diatur dalam Peraturan Pemerintah Nomor 46 Tahun 2017 tentang Instrumen Ekonomi Lingkungan Hidup maupun Peraturan Presiden Nomor 77 Tahun 2018 tentang Pengelolaan Dana Lingkungan Hidup. Selain itu, dapat pula dihasilkan dari pemberian sanksi administratif oleh Pemerintah dan/atau Pemerintah Daerah sebagaimana diatur dalam Pasal 78, 81 dan 82 UUPPLH, ataupun bersifat sukarela dari penanggung jawab usaha dan/atau kegiatan.

${ }^{18}$ Dalam hal ini, pendanaan lingkungan hidup dapat berdiri sendiri sebagaimana ditentukan dalam Pasal 42 UUPPLH maupun terikat dengan mekanisme penyelesaian sengketa di dalam dan di luar pengadilan (Pasal 85, 87 dan 88 UUPPLH) dan melalui penegakan sanksi administratif.

${ }_{19}$ Indonesia (2), Peraturan Pemerintah Instrumen Ekonomi Lingkungan Hidup, PP Nomor 46 tahun 2017, LN Nomor 228 Tahun 2017, TLN Nomor 6134, ps. 1 angka (2).

${ }^{20}$ Ibid., ps. 20 ayat (1). Lihat juga: Indonesia (3), Peraturan Presiden tentang Pengelolaan Dana Lingkungan Hidup, Perpres Nomor 77 Tahun 2018, LN Nomor 160 Tahun 2018, Ps. 3.

${ }^{21} \mathrm{Ibid}$., ps. 21 ayat (1).

${ }^{22}$ Indonesia (1), Op. Cit., ps. 55 ayat (1).

${ }^{23}$ Indonesia (2), Op. Cit., ps. 21 ayat (1).

${ }^{24}$ Ibid., ps. 22 ayat (1). 
Risk Sharing Agreement: Sebuah Ide Awal Mengenai Bentuk Alternatif Pendanaan Pemulihan Kerusakan Lahan Gambut Akibat Kebakaran Hutan dan/atau Lahan di Indonesia

Sementara itu, dana penanggulangan pencemaran dan/atau kerusakan dan pemulihan lingkungan hidup merupakan dana yang disiapkan oleh pemerintah pusat dan daerah untuk memastikan tersedianya dana untuk penanggulangan pencemaran dan/atau kerusakan lingkungan hidup dan pemulihan fungsi lingkungan hidup, menjamin terpulihkannya kembali fungsi lingkungan hidup, dan menjamin pelestarian fungsi atmosfer..$^{25}$ Dana ini hanya diperuntukkan bagi penanggulangan dan pemulihan pencemaran dan/atau perusakan lingkungan hidup yang tidak diketahui pelakunya dan/atau sumbernya. ${ }^{26}$

Lebih lanjut, Pasal 2 ayat (1) Perpres Pengelolaan Dana Lingkungan Hidup menyatakan bahwa pengelolaan dana dilakukan dengan jalan penghimpunan dana, ${ }^{27}$ pemupukan dana ${ }^{28}$ dan penyaluran dana. ${ }^{29}$ Pengelolaan dana lingkungan hidup ini dilakukan melalui kontrak/ perjanjian, ${ }^{30}$ dengan membentuk unit organisasi non-eselon yang melaksanakan fungsi pengelolaan dana lingkungan hidup dengan menggunakan pola pengelolaan keuangan badan layanan umum, dapat menunjuk, dan menetapkan Bank Kustodian sebagai trustee. ${ }^{31}$

\section{B. Pendanaan Lingkungan Hidup Melalui Penyelesaian Sengketa Di Dalam dan Di Luar Pengadilan}

Penyelesaian sengketa lingkungan hidup melalui pengadilan atau pertanggungjawaban perdata merupakan cara yang paling sering digunakan sebagai kompensasi lingkungan hidup. Pada praktiknya, terdapat dua dasar gugatan yang dapat dilakukan, yaitu perbuatan

${ }^{25}$ Ibid., ps. 26 ayat (1).

${ }^{26}$ Sumber dana untuk melaksanakan penanggulangan dan pemulihan lingkungan hidup berasal dari anggaran pendapatan dan belanja negara, anggaran pendapatan belanja daerah berasal dari pajak dan retribusi lingkungan hidup, dan/atau sumber lainnya yang sah dan tidak mengikat dengan peraturan perundang-undangan. Penggunaan dana ini dapat dilaksanakan oleh bupati/walikota, gubernur, menteri, maupun kepala lembaga non kementerian tergantung pada wilayah pencemaran dan/ atau kerusakan lingkungan hidup. Ibid., ps. 26 ayat (2) dan ps. 27 ayat (1), (2) dan (3).

${ }^{27}$ Penghimpunan dana berupa Dana Penanggulangan Pencemaran dan/atau Kerusakan dan Pemulihan Lingkungan Hidup bersumber dari Anggaran Pendapatan dan Belanja Negara, Anggaran Pendapatan dan Belanja Daerah, dan/atau sumber dana lainnya yang sah dan tidak mengikat sesuai dengan ketentuan peraturan perundang-undangan. Sementara itu, Penghimpunan dana berupa Dana Amanah/Bantuan Konservasi bersumber dari hibah dan donasi. Lihat: Indonesia (3), Op. Cit., ps. 4 ayat (1) dan (3).

${ }^{28}$ Pemupukan dana dilakukan dengan jalan instrumen perbankan, instrumen pasar modal dan/ atau instrumen keuangan lainnya sesuai dengan peraturan perundang-undangan. Pemupukan dana yang berasal dari Dana Amanah/Bantuan Konservasi dilakukan berdasarkan kesepakatan dalam kontrak/perjanjian sesuai dengan ketentuan peraturan perundang-undangan. Ibid., ps. 5.

${ }^{29}$ Penyaluran dana lingkungan hidup dilakukan sesuai dengan kesepakatan dalam kontrak/perjanjian melalui mekanisme perdagangan karbon, pinjaman, subsidi, hibah dan/atau mekanisme lainnya sesuai dengan ketentuan peraturan perundang-undangan. Ibid., ps. 6.

${ }^{30} \mathrm{Ibid} .$, ps. 7 ayat (1).

${ }^{31} \mathrm{Ibid} .$, ps. 8 ayat (1) dan 9 ayat (1). 
melawan hukum dan strict liability. Dasar hukum perbuatan melawan hukum di Indonesia secara umum terdapat pada Pasal 1365 Kitab Undang-Undang Hukum Perdata, sedangkan dalam hal perlindungan lingkungan terdapat pada Pasal 87 UUPPLH yang berbunyi,

"Setiap penanggung jawab usaha dan/atau kegiatan yang melakukan perbuatan melanggar hukum berupa pencemaran dan/atau perusakan lingkungan hidup yang menimbulkan kerugian pada orang lain atau lingkungan hidup wajib membayar ganti rugi dan/atau melakukan tindakan tertentu." 32

Berbeda dengan gugatan perbuatan melawan hukum, filosofi dan prinsip strict liability adalah penggugat tidak perlu membuktikan unsur kesalahan. ${ }^{33}$ Saat ini, penerapan strict liability di Indonesia terkait kasus lingkungan hidup terdapat pada Pasal 88 UU Nomor 32 Tahun 2009 yang menyatakan bahwa,

"Setiap orang yang tindakannya, usahanya, dan/atau kegiatannya menggunakan B3, menghasilkan dan/atau mengelola limbah B3, dan/atau yang menimbulkan ancaman serius terhadap lingkungan hidup bertanggung jawab mutlak atas kerugian yang terjadi tanpa perlu pembuktian unsur kesalahan."34

Kedua dasar gugatan tersebut dapat digunakan untuk mendapatkan pendanaan lingkungan hidup. Namun, hal ini tidak serta-merta akan mewajibkan penanggung jawab usaha dan/atau kegiatan sebagai tergugat untuk membayar ganti rugi, melainkan tergantung pada putusan pengadilan yang menentukan pemulihan dilakukan oleh penggugat atau tergugat. Jika yang melakukan pemulihan adalah penggugat, maka tergugatlah akan membayar biaya pemulihan lingkungan kepada penggugat. Sebaliknya, jika pemulihan dilakukan oleh tergugat, maka tergugat tidak wajib membayar biaya pemulihan kepada penggugat, melainkan tergugat melakukan tindakan tertentu berupa pemulihan dengan biayanya sendiri. ${ }^{35}$ Dalam konteks Indonesia, ganti rugi akan masuk ke dalam kas negara karena ketentuan me-

${ }^{32}$ Indonesia (1), Op. Cit., ps. 87 ayat (1).

${ }^{33}$ Dengan demikian, yang perlu dibuktikan dalam gugatan strict liability adalah adanya kerugian dan kausalitas antara perbuatan dan kegiatan tersebut. Lihat: Indonesian Center for Environmental Law (2), Anotasi Undang-Undang Nomor 32 Tahun 2009 tentang Perlindungan dan Pengelolaan Lingkungan Hidup (Jakarta: Indonesian Center for Environmental Law, 2014), hlm. 210.

${ }^{34}$ Indonesia (1), Op. Cit., ps. 88.

${ }^{35}$ Pada dasarnya, jika dalam kasus Pemerintah bertindak sebagai penggugat, maka permintaan tindakan pemulihan kepada tergugat dirasa kurang tepat. Hal ini sehubungan dengan apa yang disebut dengan "kewenangan pemerintahan", di mana Pemerintah dapat langsung meminta penanggung jawab usaha dan/atau kegiatan untuk melakukan tindakan pemulihan tanpa melalui proses pengadilan, yakni dengan paksaan pemerintah. Namun, pada putusan-putusan "awal" seperti pada kasus 
Risk Sharing Agreement: Sebuah Ide Awal Mengenai Bentuk Alternatif Pendanaan Pemulihan Kerusakan Lahan Gambut Akibat Kebakaran Hutan dan/atau Lahan di Indonesia

ngenai kerugian lingkungan hidup diatur dalam Pasal 90 UUPPLH, sehingga trustee di Indonesia akan identik dengan Pemerintah dan Pemerintah Daerah. ${ }^{36}$

Selain pendanaan melalui instrumen ekonomi lingkungan hidup dan penyelesaian sengketa melalui pengadilan, pendanaan pemulihan lingkungan juga dimungkinkan melalui penyelesaian sengketa di luar pengadilan. Tujuan utama dari diadakannya penyelesaian sengketa lingkungan hidup di luar pengadilan adalah untuk meminta ganti rugi yang diderita oleh para korban dan biaya pe- mulihan lingkungan hidup. ${ }^{37}$ Dalam hal ini, UUPPLH mengakomodasi penyelesaian sengketa lingkungan hidup di luar pengadilan dengan mediasi dan arbitrase, $^{38}$ yang diharapkan dapat menjadi sumber pendanaan lingkungan hidup untuk ganti rugi atau biaya pemulihan lingkungan. Terakhir, dana pemulihan lingkungan juga dapat berasal dari sanksi administratif, yakni berdasarkan Pasal 81 UUPPLH yang menyebutkan bahwa setiap penanggung jawab usaha dan/ atau kegiatan yang tidak melakukan paksaan pemerintah maka akan dikenakan denda administratif. ${ }^{39}$

Mandalawangi, Kallista Alam maupun Jatim Jaya Perkasa, masih terdapat permintaan tindakan pemulihan dari Pemerintah terhadap tergugat. Lihat: Pengadilan Negeri Bandung, Putusan Nomor 49/ PDT.G/2003/PN.Bdg tentang Gugatan Dedi, dkk Melawan Direksi Perum Perhutani, hlm. 107-109. Lihat juga: Pengadilan Negeri Meulaboh, Putusan Nomor 12/PDT.G/2012/PN.MBO tentang Gugatan Menteri Lingkungan Hidup Melawan PT Kallista Alam, hlm. 231 dan Pengadilan Negeri Jakarta Utara, Putusan Nomor 108/Pdt.G/2015/PN.Jkt.Utr. tentang Gugatan Menteri Lingkungan Hidup dan Kehutanan Melawan PT Jatim Jaya Perkasa, hlm. 170.

${ }^{36}$ Pasal 90 UUPPLH mengatur mengenai Hak Gugat Pemerintah dan Pemerintah Daerah, di mana instansi Pemerintah dan Pemerintah Daerah yang bertanggung jawab di bidang lingkungan hidup memiliki wewenang untuk mengajukan gugatan ganti rugi dan tindakan tertentu terhadap usaha dan/ atau kegiatan yang menyebabkan kerusakan dan/atau pencemaran lingkungan hidup yang mengakibatkan kerugian lingkungan hidup. Ketentuan mengenai kerugian lingkungan hidup yang diatur dalam Pasal 90 UUPPLH menyebabkan di Indonesia seolah-olah yang dapat bertindak sebagai trustee dan melakukan gugatan terhadap kerugian lingkungan hidup adalah Pemerintah dan Pemerintah Daerah semata. Seharusnya ketentuan mengenai kerugian lingkungan hidup diatur dalam pasal yang bersifat general, sehingga pihak selain Pemerintah dan Pemerintah Daerah juga dapat menjadi trustee. Di Amerika, the Comprehensive Environmental Response, Compensation, and Liability Act (CERCLA) dan the Oil Pollution Act (OPA), mengatur bahwa pihak yang dapat menjadi trustee adalah negara federal, negara bagian dan suku Indian. Bahkan, OPA mengatur pula Pemerintah Asing dapat menjadi trustee. Lihat: Indonesia (1), op. cit., Ps. 90. Lihat juga: CERCLA \$107(f)(1) dan OPA §1006(b)(5) dan §1006(c).

${ }^{37}$ Indonesian Center for Environmental Law (2), Op. Cit., hlm. 204.

${ }^{38}$ Walaupun masih terdapat perdebatan terkait dengan penyelesaian sengketa lingkungan hidup melalui arbitrase, namun hal ini masih dimungkinkan oleh UUPPLH. Lihat: Indonesia (1), Op. Cit., Ps. 85 ayat (3).

${ }^{39} \mathrm{Ibid} .$, ps. 81. Dalam Pasal 78, disebutkan bahwa pemberian sanksi administrasi tidak menghapuskan kewajiban pemulihan. Kemudian, dalam hal ini, penggunaan istilah "denda administratif" dalam Pasal 81 dianggap tidak tepat karena pada dasarnya, denda administratif diberlakukan pada saat terjadinya pelanggaran, dan bukan merupakan respons atas tidak dilakukannya paksaan pemerintah oleh 


\section{Penerapan Risk Sharing Agree- ment Sebagai Alternatif Sistem Pendanaan Pemulihan Kerusak- an Lahan Gambut Akibat Keba- karan Hutan dan/atau Lahan Di Indonesia}

\section{A. Perjanjian Pembagian Risiko (Risk Sharing Agreement)}

Perjanjian pembagian risiko (risk sharing agreement $)^{40}$ merupakan alternatif mekanisme kompensasi yang sangat atraktif terutama ketika informasi tentang probabilitas dan besarnya kerugian masih sangat kurang. ${ }^{41}$ Pada dasarnya, risiko merupakan kemungkinan dan konsekuensi atas terjadinya suatu peristiwa di masa depan yang tidak pasti dan kemungkinan tersebut merupakan suatu peristiwa yang tidak diinginkan, yang dapat mengakibatkan kerugian ${ }^{42}$ atau potensi perolehan yang tidak disadari. ${ }^{43}$ Salim menyebutkan bahwa risiko adalah suatu ketidakpastian (uncertainty) yang dapat mengakibatkan kerugian (loss). ${ }^{44}$ Sementara itu, Hartono, mengartikan risiko sebagai suatu ketidakpastian atas terjadi atau tidak terjadinya suatu peristiwa yang bersifat spekulatif. ${ }^{45}$ Berdasarkan tiga definisi yang telah disebutkan di atas, unsur yang terdapat pada risiko adalah suatu ketidakpastian dan kerugian. Secara sederhana, dapat dipahami bahwa ketidakpastian akan menimbulkan kerugian. ${ }^{46}$

pihak yang dikenakan sanksi atau pelanggar. Adapun sanksi berupa pembayaran oleh pelanggar yang tidak melakukan paksaan pemerintah disebut dengan uang paksa/dwangsom dan bukanlah ditujukan sebagai hukuman, tetapi sebagai upaya untuk mendorong pelanggar/penerima sanksi memperbaiki keadaan dan menghentikan pelanggarannya. Lihat: Andri G. Wibisana (2), "Tentang Ekor yang Tak Lagi Beracun: Kritik Konseptual atas Sanksi Administratif dalam Hukum Lingkungan di Indonesia," dalam Jurnal Hukum Lingkungan Indonesia, Vol. 6, No. 1, (Oktober 2019), hlm. 47-48 dan 64-65.

${ }^{40}$ Faure dan Jing menyebutkan bahwa risk sharing agreement memiliki beberapa nama lain dalam penyebutannya, seperti Risk Sharing Institution atau mutuals. Lihat: Michael Faure dan Liu Jing, "Risk-Sharing Agreement to Cover Environmental Damage: Theory and Practice," International Environmental Agreements: Politics, Law and Economics Vol. 18 (2018), hlm. 257.

${ }^{41}$ Berbeda dengan asuransi, di mana premi ditentukan berdasarkan informasi mengenai kerugian, perjanjian pembagian risiko dapat tetap berjalan meskipun informasi tersebut masih sangat sedikit, sebab yang dibutuhkan dalam perjanjian ini adalah kontribusi relatif dari pihak-pihak yang terlibat dalam perjanjian. Selain itu, perjanjian ini pun dapat berfungsi sebagai upaya untuk mengontrol moral hazard, karena setiap pihak yang terlibat dalam perjanjian ini memiliki kepentingan untuk mengontrol kinerja pihak lain guna mengurangi kemungkinan terjadinya kerugian. Lihat: Andri G. Wibisana dan Pramita K. Putri, "Analisa Law and Economics atas Kompensasi dan Asuransi Lingkungan di Indonesia: Sebuah Kritik Atas Kompensasi Tanpa Sistem", dalam Jurnal Hukum dan Pembangunan, Tahun ke-39, No.4 (Oktober-Desember, 2009), hlm. 539-540.

${ }^{42}$ Seperti kebakaran, banjir, kerugian finansial, dan kerusakan lainnya.

${ }^{43}$ Seperti penjualan produk baru yang tidak sesuai dengan target, keuntungan investasi yang tidak sesuai ekspektasi, ekosistem yang rusak, atau kesempatan lainnya yang tidak tercapai. Lihat: Charles Yoe, Primer on Risk Analysis Decision Making Under Uncertainity," (Boca Raton: CRC Press, 2012), hlm. 1.

${ }^{44}$ Abbas Salim, Asuransi \& Manajemen Resiko, Ed.2, Cet. 9 (Jakarta: PT RajaGrafindo Persada, 2007), hlm. 4

${ }^{45}$ Sri Rejeki Hartono, Hukum Asuransi dan Perusahaan Asuransi, Cet. 4 (Jakarta: Sinar Grafika, 2001), hlm. 15.

${ }^{46}$ Abbas Salim, Op. Cit. 
Risk Sharing Agreement: Sebuah Ide Awal Mengenai Bentuk Alternatif Pendanaan Pemulihan Kerusakan Lahan Gambut Akibat Kebakaran Hutan dan/atau Lahan di Indonesia

Ide utama dari penerapan risk sharing agreement adalah dengan menyebarkan risiko kepada para pencemar, bukan mengalihkan biaya yang terjadi akibat risiko kepada asuransi komersial. ${ }^{47}$ Secara sederhana, risk sharing agreement adalah perjanjian antara dua atau lebih pihak yang telah mengetahui suatu risiko dan setuju untuk membagi kerugian yang dapat terjadi akibat risiko. ${ }^{48}$ Mekanisme ini dilakukan dengan mendirikan suatu usaha bersama antara para pihak-pihak yang memiliki suatu usaha atau kegiatan yang sama. ${ }^{49}$

Faure dan Jing menyebutkan bahwa risk sharing agreement ${ }^{50}$ adalah suatu pendanaan (dalam bentuk perjanjian) yang mengumpulkan dana dari para anggotanya untuk membayar atau menutupi suatu tanggungan, dalam hal ini adalah risiko yang dapat terjadi terhadap lingkungan. Ide utama dari risk sharing agreement adalah untuk mendistribusikan risiko pada sesama pelaku usaha yang memiliki tanggung jawab risiko ling- kungan yang sama. Pengumpulan dana biasanya dilakukan dengan mekanisme pool, yakni suatu kumpulan orang atau badan usaha dalam sektor usaha yang sama untuk mengumpulkan dana yang kemudian diserahkan kepada anggota pengurus atau komite yang bertanggung jawab untuk mengumpulkan dan mengolah dana yang diberikan. ${ }^{51}$

\section{B. Penerapan Risk Sharing Agree- ment Pada Sektor Nuklir dan Kelautan}

Risk sharing agreement dikenal dalam beberapa sektor, di antaranya pada sektor nuklir dan kelautan. Pada bagian ini, akan dibahas mengenai penerapan risk sharing agreement pada kedua sektor tersebut.

\section{Penerapan Risk Sharing Agree- ment pada Sektor Nuklir}

Penerapan risk sharing agreement pada sektor nuklir diatur dalam The Price Anderson Act. ${ }^{52}$ Ide utama dari The Price Anderson Act adalah mengatur mengenai

${ }^{47}$ Liu Jing, Compensating Ecological Damage: Comparative and Economic Observations (Cambridge: Intersentia Ltd., 2013), hlm. 131.

${ }^{48}$ Risk sharing agreement adalah suatu perjanjian timbal balik, artinya perjanjian tersebut menimbulkan hak dan kewajiban kepada masing-masing pihak, serta hak dan kewajiban tersebut memiliki hubungan antara satu dengan yang lainnya. Lihat: J. Satrio, Hukum Perjanjian, Perikatan yang Lahir dari Perjanjian Buku I, (Bandung: Citra Aditya Bakti, 1995), hlm. 5.

${ }^{49}$ Out Sourcing Law Global, "Risk sharing agreement," http:/ / www.outsourcing-law.com/risk-sharing-agreements/, diakses pada 13 Maret 2019.

50 Michael Faure dan Liu Jing, Op. Cit., hlm. 257.

${ }^{51}$ The Law Dictionary, "What is Pool?," https://thelawdictionary.org/pool , diakses pada 13 Maret 2019.

${ }^{52}$ Awal mula Risk sharing agreement pada sektor nuklir berawal pada pertengahan tahun 1950-an di Amerika Serikat. Pada saat itu, terdapat suatu kekhawatiran akan terjadinya kecelakaan pada saat menjalankan usaha pada sektor nuklir. Minimnya informasi mengenai segala risiko yang dapat terjadi 
perlindungan finansial yang dipersiapkan oleh pelaku usaha pada sektor nuklir di Amerika Serikat. ${ }^{53}$ Awalnya, perlindungan finansial dibuat dalam dua tingkatan. Pada tingkat pertama, masing-masing pelaku usaha diwajibkan untuk menyediakan asuransi pribadi hingga batas tertentu. Kemudian, mekanisme ini disesuaikan dengan mewajibkan pelaku usaha nuklir untuk ikut serta dalam pooling yang beranggotakan pelaku usaha pada sektor nuklir. ${ }^{54}$ Anggota dalam pooling diwajibkan untuk berkontribusi secara relatif untuk membentuk suatu dana asuransi yang disebut dengan Secondary Financial Protection Program. Secondary Financial Protection Program ini akan dipakai apabila dana pada tingkat pertama tidak mencukupi untuk membayar atau menutupi kerugian yang terjadi akibat kecelakaan nuklir. ${ }^{55}$
Saat ini The Price Anderson Act masih mewajibkan para anggotanya untuk memiliki perlindungan finansial pada tingkat pertama sejumlah USD 475,000,000. Apabila perlindungan finansial pada tingkat pertama tidak mencukupi untuk membayar atau menutupi jumlah kerugian yang terjadi, maka Secondary Financial Protection Program akan disertakan untuk membayar atau menutupi kekurangannya. Masing-masing anggota diwajibkan untuk berkontribusi dengan jumlah dana maksimal sebesar USD 131,056,000 per reaktor, sehingga jumlah dana yang dapat ditanggung oleh Secondary Financial Protection Program sebesar USD 12,900,000,000 yang berasal dari 98 reaktor. Apabila pengadilan menetapkan bahwa dana ini tidak mencukupi untuk membayar kerugian yang terjadi, setiap anggota diwajibkan untuk mengumpul-

membuat suatu ketakutan tersendiri. Oleh karena itu, tercetus suatu gagasan untuk membentuk The Price Anderson Act pada tahun 1957 dengan tujuan mendukung pengembangan sektor nuklir swasta, menjadi fondasi hukum dalam menangani klaim pertanggung jawaban dalam sektor nuklir, dan mempersiapkan dana siap pakai untuk mengganti kerugian yang disebabkan oleh kecelakaan nuklir. The Price Anderson Act mewajibkan para pemilik reaktor nuklir untuk memiliki jaminan finansial yang disiapkan untuk membayar klaim public liability claim, baik klaim atas luka-luka atau kerugian properti, yang disebabkan oleh kecelakaan nuklir. Lihat: Michael Faure dan Liu Jing, Risk-Sharing Agreement to Cover Environmental Damage, hlm. 268. Lihat juga: Richard Jones, «The Price-Anderson Act,» https:// inis.iaea.org/collection/NCLCollectionStore/_Public/31/051/31051426.pdf diakses pada 10 Maret 2020.

${ }^{53}$ Mekanisme risk sharing agreement berdasarkan The Price Anderson Act yang berlaku pada sektor nuklir ini pada dasarnya memiliki konsep/model seperti asuransi. Hanya saja dalam hal ini, yang melakukan perjanjian adalah sesama pengusaha yang bergerak dalam bidang nuklir untuk membagi risiko karena mereka lah yang memiliki pengetahuan mengenai tingkat risiko dan dapat mengawasi kegiatan sama lain. Hal ini yang membedakan dengan asuransi, di mana para anggota memiliki informasi dan pengetahuan yang mumpuni mengenai tingkat risiko dan kegiatan yang mereka lakukan.

${ }^{54}$ Mekanisme pooling antara para pelaku usaha pada sektor nuklir ini juga disebut sebagai Secondary Financial Protection Program. Lihat: Taylor Meehan, "Lesson from The Price-Anderson Nuclear Industry Indemnity Act for Future Clean Energy Compensatory Models," Connecticut Insurance Law Journal Vol. 18.1 (2011), hlm. 345.

${ }^{55}$ Ibid., hlm. 344. 
Risk Sharing Agreement: Sebuah Ide Awal Mengenai Bentuk Alternatif Pendanaan Pemulihan Kerusakan Lahan Gambut Akibat Kebakaran Hutan dan/atau Lahan di Indonesia

kan dana sebesar 5\% dari kontribusi relatif yang diberikan, yaitu sebesar USD 6,553,000.56 Apabila dana ini masih kurang, kongres akan menentukan kebutuhan dana tambahan untuk membayar kerugian yang terjadi..$^{57}$

\section{Penerapan Risk Sharing Agree- ment pada Sektor Kelautan}

Penerapan risk sharing agreement pada sektor kelautan ditemui dalam Protection and Indemnity Clubs (P\&I Clubs), yang pada praktiknya bertanggung jawab atas berbagai macam risiko yang dapat terjadi pada anggota klubnya, termasuk risiko kerugian lingkungan hidup. ${ }^{58} \mathrm{Hal}$ ini dituangkan dalam satu buku yang disebut sebagai rulebook..$^{59}$

Agar dapat mengontrol dan menilai risiko yang dapat terjadi, P\&I Clubs mewajibkan para calon anggota untuk memberikan informasi-informasi yang relevan terkait risiko yang dapat terjadi kepada kapalnya, sedangkan anggota lama diwajibkan untuk memperbarui informasi mengenai kapalnya. Informasi ini akan digunakan untuk mengelompokkan anggota dan calon anggota ke dalam klasifikasi tertentu yang ditentukan oleh manajer klub. ${ }^{60}$

Sumber dana yang dipakai untuk membiayai risiko-risiko yang dapat ditanggung sesuai dengan rulebook dikumpulkan melalui mekanisme pool yang dilakukan oleh masing-masing anggota klub. Berbeda dengan rulebook, pool pada PEI Clubs berada di bawah tanggung jawab The International Group of Protection $\mathcal{E}$ Indemnity Clubs. Saat ini, pool dapat membayar kemungkinan tanggung jawab hingga USD 3,100,000,000 dan maksimal USD 1,000,000,000 untuk membayar tanggung jawab akibat pencemaran minyak. ${ }^{61}$

${ }^{56} 5 \%$ dihitung dari kontribusi relatif saat ini, yaitu USD 131,056,000.

${ }^{57}$ United States Nuclear Regulatory Commission, "Backgrounder on the Three Miles Island Accident," https:/ / www.nrc.gov/ reading-rm/doc-collections/fact-sheets/nuclear-insurance.html\#require, diakses pada 10 Juni 2019.

${ }^{58}$ Tanggung jawab P\&I Clubs atas berbagai macam risiko yang dapat terjadi pada anggota klubnya terkait dengan apa yang disebut Faure sebagai adverse selection. Adverse selection terjadi apabila asuransi gagal mengaitkan antara risiko tertanggung dengan premi yang harus dibayarnya, di mana idealnya premi yang dibayarkan oleh tertanggung harus mencerminkan risiko dari tertanggung. Apabila hal ini tidak terjadi, maka mereka yang berisiko tinggi memiliki premi yang relatif sama dengan mereka yang berisiko rendah, sehingga asuransi hanya akan menguntungkan mereka yang berisiko tinggi dan merugikan mereka yang berisiko rendah. Hal ini dapat mengakibatkan industri asuransi karena asuransi hanya diisi oleh mereka yang memiliki risiko tinggi saja. Lihat: Michael Faure, "A Shift Toward Alternative Compensation Mechanisms for Environmental Damage?", dalam Michael Faure and A. Verheij, Ed., Shifts in Compensation for Environmental Damage, (Vienna: Springer, 2007), hal. 75-78. Lihat juga: Wibisana (1), Op. Cit., hlm. 227.

${ }^{59}$ Namun, The International Group of Protection $\mathcal{E}$ Indemnity Clubs tidak mengatur mengenai rulebook tersebut. Rulebook dibuat oleh masing-masing member klub dari The International Group of Protection $\mathcal{E}$ Indemnity Clubs.

${ }^{60}$ Ibid.

${ }^{61}$ Michael Faure dan Liu Jing, Op. Cit., hlm. $264-265$. 
Pool yang dilakukan pada P\&I Clubs didasari pada perjanjian $e x$-ante $e^{62}$ antara para pemilik kapal dengan kontribusi tidak dilakukan di awal. Perjanjian tersebut menentukan bahwa, "each member should bear his aliquot share of the losses of the year covered by the policy." ${ }^{63}$ Sebelum tahun selanjutnya berjalan, manajer klub akan berkumpul dan menghitung kemungkinan klaim dan biaya operasional yang dibutuhkan pada tahun selanjutnya dan menentukan jumlah uang yang perlu dibayarkan di awal atau biasa disebut dengan advance call. ${ }^{64}$ Sementara itu, sisa dana lainnya akan dipungut melalui supplementary call yang hanya akan dilakukan apabila dana yang terkumpul dari advance call tidak mencukupi untuk membayar klaim yang terjadi dan jumlah kontribusi. Apabila pada suatu tahun jumlah klaim melebihi jumlah dana yang ditentukan dalam perjanjian, maka dana tambahan yang dipungut melalui overspill call ${ }^{65}$ akan digunakan. Berdasarkan penjelasan ini, dapat dipahami bahwa PEI Clubs terbentuk atas dasar sukarela para pengusaha untuk menggunakan risk sharing agreement dengan menerapkan dua model tata cara pemberian kontribusi, ${ }^{66}$ yaitu Advance call yang dikumpulkan melalui cara ex-ante dan supplementary call dan overspill call yang dikumpulkan dengan cara ex-post. ${ }^{67}$

${ }^{62}$ Ex-ante diartikan sebagai penghitungan yang dilakukan sebelum terjadinya suatu kejadian. Lihat: Cambridge Dictionary, "Ex Ante," https:// dictionary.cambridge.org/dictionary/english/ex-ante diakses pada 2 April 2020.

${ }^{63}$ Terjemahan bebas: setiap anggota menanggung sebagian kerugian per tahun yang telah dibayar atau ditutupi oleh kebijakan." Lihat Michael Faure dan Liu Jing, Op. Cit., hlm. 265.

${ }^{64}$ Walaupun pembayaran advance call dimintakan diawal, pembayaran dapat dilakukan dengan cara dicicil pada tahun berjalan.

${ }^{65}$ Overspill call dipungut setiap tahun oleh Protection and Indemnity Club. Lihat: International Group of P\&I Clubs, "2019/20 Pool and GXL Reinsurance Contract Structure," https:/ / www.igpandi.org/reinsurance, diakses 11 Juni 2019.

${ }^{66} \mathrm{Hal}$ inilah yang membedakan dasar pemberlakuan risk sharing agreement pada bidang kelautan melalui PEI dengan risk sharing agreement dalam bidang nuklir yang didasarkan pada The Price Anderson Act, di mana risk sharing agreement dalam bidang kelautan ini bersifat sukarela berdasarkan perjanjian dari para pengusaha atau pelaku usaha. Hal ini diawali dari ikatan sosial yang mempunyai kesamaan kepentingan mirip seperti koperasi dari pemilik pengusaha kapal yang dikenal sebagai "The Ship - owner Mutual Society", yaitu perserikatan sosial untuk membela kepentingan bersama para pemilik/pengusaha kapal dalam usaha untuk menghadapi tuntutan klaim ganti rugi terhadap hilang/ rusaknya barang dagangan yang diangkut kapal dari pihak pengguna jasa/pemilik muatan. Lihat: F.X. Sugiyanto, Hukum Asuransi Maritim: Protection \& Indemnity (PEI) Insurance, (Jakarta: Salemba Humanika, 2009), hlm. 61.

${ }^{67}$ Michael Faure dan Liu Jing, Op. Cit., hlm. 264. 
Risk Sharing Agreement: Sebuah Ide Awal Mengenai Bentuk Alternatif Pendanaan Pemulihan Kerusakan Lahan Gambut Akibat Kebakaran Hutan dan/atau Lahan di Indonesia

\section{Penerapan Risk Sharing Agree- ment Sebagai Alternatif Sistem Pendanaan Pemulihan Kerusak- an Lahan Gambut Akibat Keba- karan Hutan dan/atau Lahan di Indonesia}

\section{Urgensi Penerapan Risk Sharing Agreement di Indonesia}

Di Indonesia, pertanggungjawaban terkait kebakaran hutan dan/atau lahan diwujudkan dalam bentuk gugatan strict liability. Ketentuan ini ditemukan dalam Pasal 49 Undang-Undang Nomor 41 Tahun 1999 tentang Kehutanan (UU Kehutanan) yang menyebutkan bahwa pemegang hak atau izin usaha bertanggung jawab atas terbakarnya areal hutan di areal kerjanya. ${ }^{68} \mathrm{Hal}$ ini dipertegas oleh
Pasal 30 ayat (1) Peraturan Pemerintah Nomor 45 Tahun 2004 tentang Perlindungan Hutan (PP Perlindungan Hutan) yang menyebutkan bahwa pemegang izin pemanfaatan hutan, pemegang izin penggunaan kawasan hutan, atau pemilik hutan hak bertanggung jawab atas terjadinya kebakaran hutan di areal kerjanya, dengan bentuk pertanggungjawaban pidana, perdata, membayar ganti rugi, dan/atau sanksi administrasi. ${ }^{69}$ Kedua pasal tersebut dianggap sebagai perwujudan strict liability karena pada pasal-pasal tersebut tidak memasukkan unsur kesalahan sebagai syarat dari pertanggungjawaban. ${ }^{70}$

Kemudian, Peraturan Pemerintah Nomor 4 Tahun 2001 tentang Pengen-

${ }^{68}$ Indonesia (4), Undang-Undang tentang Kehutanan, UU Nomor 41 Tahun 1999, LN Nomor 167 Tahun 1999, TLN Nomor 3888, ps. 49.

${ }^{69}$ Indonesia (5), Peraturan tentang Pemerintah Perlindungan Hutan, PP Nomor 45 Tahun 2004, LN. No. 147 Tahun 2004, TLN No. 4453, ps. 30 ayat (1) dan 2.

${ }^{70}$ Wibisana menyatakan bahwa ketentuan Pasal 30 ayat (1) PP Perlindungan Hutan tidak menggunakan strict liability secara tepat. Hal ini dikarenakan adanya kata "kecuali" dalam penjelasan pasal tersebut, sehingga dapat diartikan bahwa pemegang hak/izin dapat lepas dari pertanggungjawaban jika mampu membuktikan dirinya tidak bersalah yang dapat diartikan adanya pembuktian terbalik unsur kesalahan. Dengan demikian, maka unsur kesalahan dianggap telah terbukti dan menjadi beban pemegang hak/izin untuk membuktikan sebaliknya. Penggunaan strict liability yang keliru ini dapat ditemukan dalam Putusan Nomor 591/Pdt.G-LH/2015/PN JKT.SEL (Menteri LHK melawan PT National Sago Prima) dan Putusan Nomor 51/PDT/2016/PT.PLG (Menteri LHK melawan PT Bumi Mekar Hijau). Dalam Putusan Nomor 591/Pdt.G-LH/2015/PN JKT.SEL, Majelis Hakim menyatakan bahwa perbuatan Tergugat yang menyebabkan pencemaran dan/atau kerusakan lingkungan hidup sebagai akibat lalainya tergugat mengantisipasi kerusakan hutan dalam terjadinya kebakaran adalah perbuatan melawan hukum, walaupun pasal yang digunakan adalah Pasal 49 UU Kehutanan, Pasal 30 PP Perlindungan Hutan dan Pasal 18 PP Nomor 4 Tahun 2001. Selanjutnya, dalam Putusan Nomor 51/PDT/2016/PT.PLG Majelis Hakim juga menyatakan bahwa Tergugat/terbanding dianggap tidak melaksanakan kewajiban hukumnya dan harus bertanggungjawab atas terjadinya kebakaran tersebut, walaupun pasal-pasal yang digunakan mengandung strict liability. Lihat: Andri G. Wibisana (1), op. cit., hlm. 106, 126-127 dan 128-129. Lihat juga: Pengadilan Negeri Jakarta Selatan, Putusan Nomor 591/Pdt.G-LH/2015/PN JKT.SEL tentang Gugatan Menteri Lingkungan Hidup dan Kehutanan melawan PT National Sago Prima, hlm. 402-403 dan Pengadilan Tinggi Palembang, Putusan Nomor 51/PDT/2016/ PT.PLG tentang Gugatan Banding Menteri Lingkungan Hidup dan Kehutanan melawan PT Bumi Mekar Hijau, hlm. 168-169. 
dalian Kerusakan dan atau Pencemaran Lingkungan Hidup yang Berkaitan dengan Hutan dan/atau Lahan (PP Nomor 4 Tahun 2001) menyatakan bahwa penanggung jawab usaha/kegiatan wajib melakukan tindakan penanggulangan apabila terjadi kebakaran hutan dan lahan, dan wajib melakukan pemulihan dampak lingkungan hidup akibat kebakaran hutan dan lahan. ${ }^{71}$ Selanjutnya, dalam Peraturan Pemerintah Nomor 71 Tahun 2014 tentang Perlindungan dan Pengelolaan Ekosistem Gambut (PP Perlindungan Gambut) menyebutkan bahwa penanggung jawab usaha/kegiatan yang melakukan pemanfaatan ekosistem gambut yang menyebabkan kerusakan wajib melakukan penanggulangan dan pemulihan sesuai dengan kewajiban yang tercantum pada izin lingkungan. ${ }^{72}$ Berdasarkan hal tersebut dapat disimpulkan bahwa penanggung jawab usaha/kegiatan yang melakukan usahanya pada hutan dan/atau lahan gambut wajib untuk menjaga dan memulihkannya.
Namun, seperti disebutkan pada bagian sebelumnya, permasalahan utama pemulihan lingkungan hidup adalah sumber pendanaan. Hingga saat ini, kerugian ekologis serta biaya pemulihan lingkungan hidup telah ditetapkan sebesar Rp 2.718.734.023.400,00 yang berasal dari delapan putusan. ${ }^{73}$ Namun, seluruh dana tersebut belum terkumpul sebab seluruh putusan pengadilan tersebut belum dieksekusi ${ }^{74}$ dimana salah satu alasannya adalah tergugat berpotensi mengalami insolvensi karena jumlah uang yang dibutuhkan untuk menutupi kerugian dan pemulihan lingkungan hidup dapat melebihi jumlah aset yang dimiliki oleh tergugat, yang disebut judgement proof. ${ }^{75}$ Menurut Faure, dalam konteks pencemaran dan/atau perusakan lingkungan hidup dapat berimplikasi kepada tiga hal, yaitu berkurangnya tingkat pencegahan yang dilakukan oleh pelaku usaha (under-deterrence), berkurangnya nilai ganti rugi yang diterima oleh korban (under-compensation), dan terjadinya externalization through insolvency. ${ }^{76}$ De-

\footnotetext{
${ }^{71}$ Indonesia (6), Peraturan Pemerintah Pengendalian Kerusakan dan atau Pencemaran Lingkungan Hidup yang Berkaitan dengan Kebakaran Hutan dan/atau Lahan, PP Nomor 4 Tahun 2001, LN Nomor 10 Tahun 2001, TLN Nomor 4076, ps. 18 ayat (1) dan 21 ayat (1).

${ }^{72}$ Indonesia (7), Peraturan Pemerintah tentang Perlindungan dan Pengelolaan Ekosistem Gambut, PP Nomor 71 Tahun 2014, LN No. 209 Tahun 2014, TLN No. 5580, ps. 27 ayat (1) dan 30 ayat (1).

${ }^{73}$ Indonesian Center for Environmental Law (1), Op. Cit., hlm. 3 - 4.

${ }^{74}$ Sekitar $67 \%$ dari total nilai kerugian lingkungan hidup ditujukan untuk pemulihan lingkungan hidup. Bercermin pada kondisi ini, dapat diketahui bahwa belum ada tindakan pemulihan pada lahan bekas terbakar pada area konsesi sebagai bagian dari eksekusi putusan. Ibid.

${ }^{75}$ S. Shavel, "The Judgement Proof Problem," International Review of Law and Economics (1986), hlm. 45.

${ }^{76}$ Semakin tingginya potensi jumlah kerugian lingkungan yang harus dibayarkan oleh pencemar, pihak pencemar tentu akan semakin berhati-hati dalam menjalankan usahanya. Sebaliknya, ketika pihak pencemar mengetahui bahwa aset yang dimilikinya tidak akan cukup untuk membayar potensi ganti rugi kerugian lingkungan hidup, secara sendirinya pihak pencemar akan mengurangi tingkat
} 
Risk Sharing Agreement: Sebuah Ide Awal Mengenai Bentuk Alternatif Pendanaan Pemulihan Kerusakan Lahan Gambut Akibat Kebakaran Hutan dan/atau Lahan di Indonesia

ngan demikian, dibutuhkan suatu alternatif pendanaan pemulihan lingkungan hidup yang dapat diwujudkan dalam bentuk risk sharing agreement.

\section{Mekanisme Penerapan Risk Sharing Agreement pada Sektor Gambut di Indonesia}

Saat ini, risk sharing agreement belum menjadi suatu alternatif pendanaan kerugian lingkungan hidup di Indonesia. Namun, bukan berarti risk sharing agreement tidak dapat diterapkan. Risk sharing agreement sangat mungkin diterapkan, terutama pada usaha yang dilakukan di atas lahan gambut yang tanggung jawabnya berupa strict liability. ${ }^{77}$ Sebagai salah satu usaha yang sering disebut sebagai penyebab kebakaran hutan dan lahan gambut di Indonesia, artikel ini akan mengangkat usaha perkebunan kelapa sawit yang berada di atas lahan gambut. Dalam hal usaha perkebunan kelapa sawit, setidaknya terdapat beberapa hal yang perlu diperhatikan, yakni: ${ }^{78}$

a. Bentuk dan ruang lingkup. Risk sharing agreement merupakan pendana-

kehati-hatiannya untuk menjaga terjadinya pencemaran. Hal inilah yang disebut under-deterrence. Kemudian, kompensasi secara penuh terjadi ketika kompensasi yang diberikan dapat mengembalikan utilitas korban sama dengan utilitas yang dimilikinya saat sebelum pencemaran terjadi. Ketika insolvensi terjadi dan kompensasi yang diterima oleh para korban kurang dari yang seharusnya, para korban tetap akan mengalami kerugian. Terakhir, externalization through insolvency adalah munculnya eksternalitas negatif yang disebabkan oleh kurangnya aset yang dimiliki oleh pencemar untuk memulihkan lingkungan hidup. Pada akhirnya lingkungan yang tercemar dan/atau rusak menjadi beban pihak lain, seperti masyarakat sekitar atau pemerintah, yang seharusnya tidak perlu membayar kerugian lingkungan hidup tersebut. Hal ini pun bertentangan dengan prinsip polluter pays principle. Lihat: Andri G. Wibisana dan Pramita K. Putri, Op. Cit. hlm. 536 - 537.

${ }^{77}$ Strict liability dapat dilihat berdasarkan undang-undang maupun berdasarkan putusan pengadilan (tradisi common law). Jika dilihat berdasarkan undang-undang, maka strict liability untuk suatu kegiatan ditetapkan di dalam undang-undang. Dalam hal ini, maka rumusan atau kriteria kegiatan yang dapat dikenakan strict liability didefinisikan dengan jelas, termasuk pula mengenai batas pertanggungjawaban dan kewajiban adanya jaminan keuangan. Oleh karena itu, jika suatu kegiatan memenuhi rumusan atau kriteria kegiatan yang diatur dalam undang-undang tersebut, maka penanggung jawab usaha dan/atau kegiatan akan langsung terkena strict liability. Sementara itu, jika dilihat berdasarkan putusan pengadilan (common law), maka pertanggungjawaban berdasarkan strict liability harus melalui pengadilan. Di Indonesia, ketentuan mengenai strict liability di UUPPLH dapat dikatakan tidak konsisten. Hal ini dikarenakan dalam Pasal 88 UUPPLH yang mengatur mengenai strict liability mengandung unsur strict liability berdasarkan undang-undang maupun berdasarkan pengadilan. Jika dilihat dari frasa "menggunakan B3" maupun "menghasilkan atau mengolah B3", maka UUPPLH dikatakan mengadopsi strict liability berdasarkan undang-undang, di mana dengan jelas disebutkan definisi kegiatan yang dapat dikenakan strict liability beserta adanya pembatasan pertanggungjawaban dan keharusan adanya asuransi pertanggungjawaban wajib yang disebutkan dalam Penjelasan Pasal 88. Namun, di sisi lain, frasa "menimbulkan ancaman serius" menyebabkan keberlakuan strict liability harus ditentukan oleh pengadilan dengan apa yang disebut "abnormally dangerous test". Hal inilah yang kemudian berlaku dalam sektor gambut di Indonesia, di mana harus ada pembuktian unsur kegiatan berbahaya dan menimbulkan ancaman serius. Namun, baik berdasarkan undang-undang maupun putusan pengadilan, keduanya tetap dikategorikan sebagai pertanggungjawaban perdata. Lihat: Andri G. Wibisana (1),Op. Cit., hlm. 111-112.

${ }^{78}$ Wawancara dengan Edward Silalahi, Pengusaha Kelapa Sawit di Provinsi Jambi, tanggal 5 Juni 2019. 
an yang bersifat sukarela, terpisah dari pendanaan lingkungan hidup yang diatur dalam peraturan perundang-undangan, dan mencakup tanggung jawab pelaku usaha yang ingin mengganti kerugian lingkungan hidup, khususnya tindakan pemulihan lingkungan hidup.

b. Para pihak. Pihak yang berperan dalam risk sharing agreement adalah para pengusaha perkebunan kelapa sawit yang kegiatan usahanya berbentuk perseroan terbatas. ${ }^{79} \mathrm{Hal}$ ini dikarenakan pelaku usaha perkebunan kelapa sawit dengan jenis perseroan terbatas cenderung memiliki arus kas yang besar. Ide ini disepakati juga oleh Silalahi yang mengatakan bahwa perkebunan kelapa sawit berbentuk perseroan terbatas memiliki modal yang relatif besar dan risiko yang dimilikinya dalam mengopera- sikan perkebunannya lebih besar dibandingkan perkebunan yang dikelola oleh masyarakat. ${ }^{80}$

c. Badan Pengelola. Risk sharing agreement dikelola oleh badan yang akan mengelola uang yang didapatkan melalui mekanisme pooling, membuat regulasi internal bagi anggota risk sharing agreement, melakukan penilaian dan pengawasan terhadap kepatuhan anggota, dan menilai kelayakan calon anggota yang hendak ikut serta. Dalam hal ini, Sahari berpendapat bahwa perlu dibentuk badan pengelola baru yang terdiri dari para pengusaha kelapa sawit dan tidak berasal dari pemerintah karena risk sharing agreement bersifat sukarela. ${ }^{81}$

d. Lingkup daerah penerapan. Luas atau sempitnya lingkup daerah penerapan secara tidak langsung akan mempengaruhi potensi jumlah ang-

${ }^{79}$ Pada dasarnya, perkebunan kelapa sawit dapat dijalankan oleh berbagai macam bentuk usaha, mulai dari perusahaan negara, perusahaan daerah, persero, perseroan terbatas, commanditair venootschap, koperasi, dan perorangan/rakyat. Lihat: Badan Pusat Statistik, Direktori Perusahaan Sawit (Jakarta: Badan Pusat Statistik, 2017), hlm. 2.

${ }^{80}$ Wawancara dengan Edward Silalahi, Pengusaha Kelapa Sawit di Provinsi Jambi, tanggal 5 Juni 2019.

${ }^{81}$ Pada dasarnya dalam pengusahaan kelapa sawit terdapat Gabungan Pengusaha Kelapa Sawit Indonesia, yakni organisasi pengusaha kelapa sawit di Indonesia dan memiliki tujuan untuk "membina dan mengembangkan kemampuan, kegiatan, dan kepentingan pengusaha kelapa sawit Indonesia, serta memadukan secara seimbang dan keterkaitan antar-potensi pengusaha kelapa sawit." Selain itu, badan ini memiliki jaringan yang luas sehingga akan bermanfaat bagi pengumpulan dana. Namun, badan ini dianggap tidak memungkinkan untuk menjadi badan pengelola dana risk sharing agreement karena memiliki fokus yang berbeda dengan risk sharing agreement itu sendiri. Sehingga, diutamakan membentuk badan baru yang bertugas mengelola dana tersebut. Namun, perlu diperhatikan karena sifatnya yang sukarela, maka badan pengelola ini sebaiknya tidak berasal dari pemerintah, melainkan berasal dari para pengusaha kelapa sawit tersebut. Lihat: Wawancara dengan Bandung Sahari, Pengurus Gabungan Kelapa Sawit Indonesia Komp. Gambut dan Kebakaran Hutan dan Lahan, 14 Mei 2019. Lihat juga: Gabungan Pengusaha Kelapa Sawit Indonesia, "Sejarah GAPKI," https://gapki.id/introduction diakses 13 Juni 2019. 
Risk Sharing Agreement: Sebuah Ide Awal Mengenai Bentuk Alternatif Pendanaan Pemulihan Kerusakan Lahan Gambut Akibat Kebakaran Hutan dan/atau Lahan di Indonesia

gota yang dapat ikut serta dalam risk sharing agreement, yang juga akan mempengaruhi biaya administrasi, sehingga dapat mempengaruhi keunggulan komparatif dari risk sharing agreement. ${ }^{82}$ Penulis berpendapat bahwa penerapan risk sharing agreement pada perusahaan perkebunan kelapa sawit dilakukan dalam skala nasional yang mana berpotensi untuk mengumpulkan jumlah dana yang besar pada mekanisme pool. Hal ini sehubungan dengan pengusaha kelapa sawit yang berjumlah 1.826, tersebar di seluruh Indonesia, ${ }^{83}$ dan sebagian besar merupakan perkebunan besar swasta dengan jumlah 1.615 atau sekitar $91 \%$ dari jumlah total pengusaha kelapa sawit di Indonesia. ${ }^{84}$ Dengan demikian, semakin banyak pelaku usaha yang ikut serta dalam risk sharing agreement, maka akan semakin banyak jumlah dana yang dapat terkumpul dan sebaliknya.

e. Mekanisme penerapan yang terdiri dari pendaftaran anggota, mekanisme pembayaran kontribusi pada sistem pooling, penentuan jumlah dan model pendanaan, serta klaim yang dapat ditanggung.
1) Pendaftaran anggota. Pendaftaran dilakukan melalui Badan Pengelola untuk dinilai kelayakan calon anggota tersebut untuk ikut serta dalam risk sharing agreement, dengan mengumpulkan dokumen administratif dan memenuhi persyaratan wajib agar dapat dinilai layak untuk ikut serta. Dokumen-dokumen tersebut meliputi dokumen terkait izin usaha perkebunan, hak atas tanah sesuai peraturan di bidang pertanahan, izin lingkungan, dan laporan keuangan terakhir yang telah diaudit. Dokumen tersebut akan digunakan untuk mengklasifikasikan risiko yang dimiliki oleh masing-masing anggota, yakni untuk membagi risiko relatif, agar masing-masing anggota dapat memberikan kontribusi yang sebanding dengan tingkat risiko yang dimiliki.

2) Pemberian kontribusi pada pool. Menurut Silalahi, dalam pemberian kontribusi terlebih dahulu perlu dilakukan klasifikasi dengan membagi perkebunan kelapa sawit sesuai degan luas area

${ }^{82}$ Michael Faure dan Liu Jing, Op. Cit., hlm. 263.

${ }^{83}$ Persebaran ini tidaklah merata, yakni terkonsentrasi pada dua pulau, yaitu di Pulau Sumatera dan Pulau Kalimantan. Pulau Sumatera diduduki oleh 1.019 perusahaan perkebunan kelapa sawit atau $57 \%$ dari total perkebunan kelapa sawit di Indonesia. Disusul oleh Pulau Kalimantan yang diduduki oleh 680 perusahaan perkebunan kelapa sawit atau 38\% dari total perkebunan kelapa sawit di Indonesia. Sementara 3\% lainnya tersebar di Pulau Sulawesi dan 2\% sisanya tersebar di Pulau Jawa, Maluku, dan Papua. Lihat: Badan Pusat Statistik, Op. Cit., hlm. 3.

${ }^{84}$ Ibid., hlm. 4. 
usahanya, dimana semakin luas suatu perkebunan kelapa sawit, maka akan semakin besar risiko lahannya dapat terbakar. ${ }^{85}$ Selain itu, hal terpenting dalam pemberian kontribusi dalam pool adalah ketersediaan uang. ${ }^{86}$ Jika suatu area usaha memiliki area yang luas tetapi tidak produktif, maka pendapatan yang dimilikinya pun tidak akan maksimal. Oleh karena itu, sangat penting untuk mempertimbangkan kemampuan para anggota dalam risk sharing agreement untuk dapat berkontribusi kepada pool. ${ }^{87}$ Dalam hal ini, Penulis berpendapat bahwa yang seharusnya dijadikan klasifikasi adalah luasan lahan gambut yang digunakan, bukan terpaku pada luasan lahan perkebunan kelapa sawit saja. Hal ini sehubungan dengan penggunaan lahan gambut yang masuk ke dalam kategori "ancaman serius".

Kemudian, jumlah pemberian kontribusi pada tiap pembayaran akan mengacu pada pendapatan para anggota. Dalam hal ini, pe- ngumpulan dana pool dilakukan dengan menggabungkan tata cara pembayaran secara ex-ante, yakni untuk mengumpulkan dana siap pakai apabila dibutuhkan pemulihan lingkungan hidup dalam waktu cepat dan biaya operasional, dan secara ex-post yang ditujukan untuk menutupi kekurangan biaya jika dana yang terkumpul dari kontribusi secara ex-ante tidak mencukupi. Ketentuan ini mengadopsi mekanisme PEI Club yang memadukan kedua cara tersebut untuk menciptakan suatu perlindungan finansial bagi anggotanya.

3) Penentuan jumlah dan model pendanaan. Dalam hal ini, perkiraan jumlah dana untuk menutupi atau membayar klaim yang akan muncul ditentukan setiap tahun, sebagaimana diadopsi oleh PEI Club. ${ }^{88}$ Selain itu, model pendanaan yang dibuat secara berlapis juga baik untuk diterapkan oleh Badan Pengelola. Skema yang ditawarkan terdiri dari tiga lapisan dengan menetapkan

\footnotetext{
${ }^{85}$ Wawancara dengan Edward Silalahi, Pengusaha Kelapa Sawit di Provinsi Jambi, tanggal 5 Juni 2019.

${ }^{86} \mathrm{Hal}$ ini berkaitan dengan arus kas dan pendapatan yang dimiliki oleh para anggotanya. 2019.

${ }^{87}$ Wawancara dengan Edward Silalahi, Pengusaha Kelapa Sawit di Provinsi Jambi, tanggal 5 Juni

${ }^{88} \mathrm{Hal}$ ini dikarenakan dalam industri perkebunan kelapa sawit, risiko-risiko sangat beragam dan salah satunya adalah risiko yang disebabkan oleh alam, seperti dalam bidang kelautan. Risiko yang disebabkan oleh alam ini berbeda-beda di setiap tahunnya, sehingga perlu untuk menghitung ulang kemungkinan-kemungkinan yang terjadi pada tahun tersebut.
} 
Risk Sharing Agreement: Sebuah Ide Awal Mengenai Bentuk Alternatif Pendanaan Pemulihan Kerusakan Lahan Gambut Akibat Kebakaran Hutan dan/atau Lahan di Indonesia

ketentuan ambang batas bawah ${ }^{89}$ dan ambang batas atas,,$^{90}$ dengan tujuan untuk menentukan batasan pertanggungjawaban para anggotanya. ${ }^{91}$ Adapun penentuan lapisan-lapisan ini bertujuan untuk menentukan tata cara pemungutan yang dapat dilakukan dalam risk sharing agreement. Pemberian kontribusi secara $e x$ -ante dilakukan untuk menutupi kebutuhan dana yang ditentukan pada lapisan pertama. Para anggota akan dimintakan kontribusinya sebelum tahun berjalan dengan pembayaran yang dapat dicicil sesuai dengan pendapatannya pada tahun tersebut. Idealnya, cicilan dapat dibayarkan setelah anggotanya mendapat hasil panen, yaitu sekitar dua atau tiga bulan sekali. ${ }^{92}$ Sementara lapis kedua dan lapis ketiga merupakan dana yang ditentukan apabila dana pada lapisan sebelumnya tidak mencukupi untuk memba- yar klaim pada tahun tersebut, atau disebut secara ex-post.

4) Klaim yang dapat ditanggung adalah klaim untuk memulihkan lahan gambut yang tercemar atau rusak akibat kebakaran hutan dan lahan, karena yang menjadi fokus dari risk sharing agreement ini adalah penyediaan dana pemulihan lingkungan hidup. Klaim atas pemulihan lingkungan hidup ini dapat muncul karena adanya penyelesaian sengketa lingkungan hidup di luar pengadilan, di dalam pengadilan, maupun karena diberikannya sanksi administrasi, ${ }^{93}$ dengan syarat terpenuhinya ambang batas bawah dan atas yang telah ditentukan. Sebagaimana diterangkan sebelumnya, risk sharing agreement akan berkaitan dengan strict liability. Dalam hal ini, strict liability terkait kebakaran hutan dan/ atau lahan gambut tidak selalu diselesaikan di dalam pengadil-

${ }^{89}$ Ambang batas bawah adalah jumlah minimal yang harus dicapai agar dapat menggunakan dana yang terkumpul dari pool.

${ }_{90}^{90}$ Ambang batas atas adalah jumlah maksimal yang harus dicapai agar dapat menggunakan dana yang terkumpul dari pool.

${ }^{91}$ Sebagai contoh, apabila nilai klaim belum mencapai ambang batas bawah yang telah ditentukan, anggota tidak dapat meminta klaim pertanggungjawaban kepada risk sharing agreement. Namun, jika klaim pada tahun tersebut telah melebihi ambang batas atas yang telah ditentukan, maka klaim sudah tidak dapat dipertanggungjawabkan oleh risk sharing agreement.

${ }^{92}$ Wawancara dengan Edward Silalahi, Pengusaha Kelapa Sawit di Provinsi Jambi, tanggal 5 Juni 2019.

${ }^{93}$ Sanksi administrasi menurut Pasal 81 UUPPLH adalah denda untuk setiap keterlambatan pelaksanaan paksaan pemerintah. Namun, yang seharusnya diterapkan ketika pelanggar tidak melaksanakan paksaan pemerintah adalah berupa uang paksa (dwangsom). 
an. Walaupun dalam hal kebakaran hutan dan/atau lahan gambut termasuk ke dalam unsur "ancaman serius" yang merupakan bentuk common law, tidak serta-merta akan diselesaikan di dalam pengadilan. Jika para pihak sepakat menyelesaikannya di luar pengadilan, maka klaim dapat langsung diajukan tanpa membawanya ke ranah pengadilan. Sehingga, dalam hal ini bentuk strict liability tidak mempengaruhi bentuk penyelesaian sengketa, melainkan terkait dengan pembuktian apakah kegiatan tergugat merupakan ancaman serius. $^{94}$

Ketika para pihak sepakat untuk menyelesaikan sengketa di luar pengadilan ${ }^{95}$ dan pelaku usaha, bersedia melakukan pemulihan lingkungan hidup, maka klaim dapat diajukan kepada Badan Pengelola untuk dikeluarkan dana pemulihan. Namun, jika tidak terjadi kesepakatan di luar pengadilan atau sejak awal para pihak sepakat menyelesaikannya di dalam pengadilan, maka klaim dapat diajukan kepada Badan Pengelola setelah terdapat putusan pengadilan yang berkekuatan hukum tetap untuk kemudian dikeluarkan dana pemulihan lingkungan hidup dari pool.

f. Hak dan kewajiban anggota. Hal ini penting untuk mengetahui prestasi apa saja yang harus dipenuhi agar perjanjian ini dapat berjalan sesuai dengan tujuannya. Pertama, tiap anggota wajib membayar kontribusi yang diberikan kepada Badan Pengelola sesuai dengan mekanisme pool dengan tiga lapisan pembayaran. Kedua, tiap anggota menjaga pengeluaran yang diperlukan serendah-rendahnya, salah satunya dengan menjaga usaha perkebunan kelapa sawit milik masing-masing anggota

${ }^{94}$ Dalam hal ini, bentuk dari strict liability akan berpengaruh dalam hal pembuktian. Dalam hal strict liability dengan statutory model, maka tidak perlu lagi dibuktikan unsur abnormally dangerous karena kriterianya sudah ditentukan dalam undang-undang, sedangkan dalam common law model, unsur abnormally dangerous perlu dibuktikan oleh pengadilan (abnormally dangerous test). Lihat: Andri G. Wibisana (1), Op. Cit., hlm. 111-112.

${ }_{95}$ Dalam penyelesaian sengketa lingkungan hidup di luar pengadilan, hal yang perlu disepakati adalah bentuk dan besarnya ganti rugi, tindakan pemulihan akibat pencemaran dan/atau perusakan, tindakan tertentu untuk menjamin tidak akan terulangnya pencemaran dan/atau perusakan lingkungan, dan/atau tindakan untuk mencegah timbulnya dampak negatif terhadap lingkungan hidup. Kesepakatan ini dapat dicapai melalui jasa mediasi dan arbitrase. Sementara itu, kesepakatan mengenai biaya ganti rugi pemulihan lingkungan hidup nantinya dapat disepakati secara bersama. Hasil kesepakatan nantinya dapat menjadi bukti untuk mengajukan klaim Badan Pengelola. Lihat: Indonesia (1), Op. Cit., Ps. 85 ayat (1) dan (3). Lihat juga: Kementerian Lingkungan Hidup, Peraturan Menteri Lingkungan Hidup tentang Kerugian Lingkungan Hidup Akibat Pencemaran dan/atau Kerusakan Lingkungan Hidup, Permen LH Nomor 7 Tahun 2014, BN Nomor 1726 Tahun 2014, Ps. 7 ayat (1) huruf a. 
Risk Sharing Agreement: Sebuah Ide Awal Mengenai Bentuk Alternatif Pendanaan Pemulihan Kerusakan Lahan Gambut Akibat Kebakaran Hutan dan/atau Lahan di Indonesia

dari risiko kebakaran hutan dan lahan. ${ }^{96}$ Ketiga, tiap anggota melakukan pemantauan pencegahan dan penanggulangan kebakaran hutan dan lahan oleh dan antar anggota. ${ }^{97}$ Apabila kewajiban-kewajiban tersebut telah dipenuhi, maka para anggota dapat melakukan klaim pada Badan Pengelola untuk memulihkan lingkungan hidup sesuai dengan mekanisme yang telah ditentukan.

Berdasarkan hal tersebut dapat dilihat bahwa pada dasarnya risk sharing agreement merupakan suatu mekanisme pendanaan lingkungan yang bersifat sukarela di antara para pengusaha, tanpa melibatkan Pemerintah. Pendanaan ini terpisah dari dana jaminan yang diatur dalam peraturan perundang-undangan terkait karena akan dikelola oleh para pengusaha kelapa sawit tersebut, yakni melalui Badan Pengelola.

\section{Penutup}

Selama ini pendanaan atas kerusakan akibat kebakaran hutan/lahan pada sektor gambut masih mengandalkan pertanggungjawaban perdata yang utamanya dilaksanakan melalui gugatan di pengadilan. Namun, eksekusi putusan terkait pemulihan lingkungan seringkali tidak dapat dieksekusi karena biaya pemulihan yang besar dan tidak dapat dipenuhi oleh pelaku usaha, sehingga pemulihan lingkungan hidup menjadi tertunda. Oleh karena itu, dibutuhkan alternatif pendanaan berupa risk sharing agreement, dengan pengumpulan dana oleh para pengusaha melalui Badan Pengelola untuk selanjutnya dilakukan pembagian risiko yang telah diketahui oleh para pelaku usaha sejenis. Pada sektor gambut, penerapan risk sharing agreement dapat dilakukan dengan memperhatikan ruang lingkup, para pihak, badan pengelola, lingkup daerah penerapan, mekanisme penerapan yang terdiri dari pendaftaran anggota, mekanisme pembayaran kontribusi pada sistem pooling, penentuan jumlah dan model pendanaan, dan klaim yang dapat ditanggung, serta hak dan kewajiban para anggota.

${ }^{96}$ Faure dan Jing menyatakan bahwa ketika tidak ada kebakaran hutan dan lahan yang terjadi, artinya kontribusi retrospektif tidak perlu untuk dilakukan. Hal ini akan menjaga biaya risk sharing agreement agar tetap rendah. Tindakan ini merupakan cara agar risk sharing agreement dapat mencapai potensi efisiensi yang maksimal. Lihat: Michael Faure dan Liu Jing, Op. Cit., hlm. 264.

${ }^{97}$ Sebagai sesama pelaku usaha, para anggota akan memiliki pengetahuan yang lebih dalam mengenali risiko-risiko yang dapat terjadi terhadap usahanya. Pemantauan oleh para anggota ini juga penting untuk membangun rasa kepercayaan agar terbentuk rasa kebersamaan. Oleh karena itu, pemantauan bersama dan saling mengingatkan satu sama lain akan kemungkinan terjadinya suatu risiko merupakan suatu cara yang tepat untuk mencegah risiko kebakaran hutan dan lahan. Selain itu, pemantauan ini juga dapat mencegah terjadinya moral hazard yang dilakukan oleh anggotanya yang kurang bertanggung jawab. Lihat: Ibid. 


\section{DAFTAR PUSTAKA}

\section{Peraturan Perundang-undangan}

Indonesia. Undang-Undang Kehutanan. UU No. 41 Tahun 1999, LN No. 167 Tahun 1999. TLN No. 3888. - Undang-Undang Perlindungan dan Pengelolaan Lingkungan Hidup. UU No. 32 Tahun 2009. LN No. 140 Tahun 2009, TLN No. 5059.

. Peraturan Pemerintah Pengendalian Kerusakan dan atau Pencemaran Lingkungan Hidup yang Berkaitan dengan Kebakaran Hutan dan/atau Lahan. PP Nomor 4 Tahun 2001. LN Nomor 10 Tahun 2001. TLN Nomor 4076.

- Peraturan Pemerintah tentang Perlindungan Hutan. PP Nomor 45 Tahun 2004. LN. No. 147 Tahun 2004. TLN No. 4453.

Peraturan Pemerintah Perubahan atas Peraturan Pemerintah Nomor 71 Tahun 2014 tentang Perlindungan dan Pengelolaan Ekosistem Gambut. PP No. 57 No. 2016, LN No. 5957.

. Peraturan Pemerintah Instrumen Ekonomi Lingkungan Hidup. PP No. 46 Tahun 2017. LN Nomor 228 Tahun 2017, TLN Nomor 6134.

. Peraturan Presiden tentang Pengelolaan Dana Lingkungan Hidup. Perpres Nomor 77 Tahun 2018. LN Nomor 160 Tahun 2018

Kementerian Lingkungan Hidup. Peraturan Menteri Lingkungan Hidup tentang Kerugian Lingkungan Hidup Akibat Pencemaran dan/atau Kerusakan Lingkungan Hidup. Permen LH Nomor 7 Tahun 2014, BN Nomor 1726 Tahun 2014

\section{Buku}

Badan Pusat Statistik. Direktori Perusahaan Sawit. Jakarta: Badan Pusat Statistik, 2017.

Badan Restorasi Gambut. Rencana Strategis Badan Restorasi Gambut 2016 2020. Jakarta: Badan Restorasi Gambut, 2016.

Faure, Michael. "A Shift Toward Alternative Compensation Mechanisms for Environmental Damage?" Dalam Michael Faure and A. Verheij, Ed., Shifts in Compensation for Environmental Damage. Vienna: Springer, 2007.

Hartono, Sri Rejeki. Hukum Asuransi dan Perusahaan Asuransi. Cet. 4. Jakarta: Sinar Grafika, 2001.

Indonesian Center for Environmental Law. Anotasi Undang-Undang Nomor 32 Tahun 2009 tentang Perlindungan dan Pengelolaan Lingkungan Hidup. Jakarta: Indonesian Center for Environmental Law, 2014. Catatan Awal Tahun 2019 Indonesian Center for Environmental Law: Narasi yang Hilang dalam Proyeksi Kebijakan Lingkungan Hidup Capres-Cawapres. Jakarta.: Indonesian Center for Environmental Law, 2019.

Jing, Liu. Compensating Ecological Damage: Comparative and Economic Observations. Cambridge: Intersentia Ltd., 2013.

Kementerian Lingkungan Hidup dan Kehutanan. The State of Indonesia's Forests 2018. Jakarta: Kementerian Lingkungan Hidup dan kehutanan Republik Indonesia, 2018. 
Risk Sharing Agreement: Sebuah Ide Awal Mengenai Bentuk Alternatif Pendanaan Pemulihan Kerusakan Lahan Gambut Akibat Kebakaran Hutan dan/atau Lahan di Indonesia

Salim, Abbas. Asuransi \& Manajemen Resiko. Ed.2. Cet. 9. Jakarta: PT RajaGrafindo Persada, 2007.

Satrio, J. Hukum Perjanjian, Perikatan yang Lahir dari Perjanjian Buku I. Bandung: Citra Aditya Bakti, 1995.

Sugiyanto, F.X. Hukum Asuransi Maritim: Protection \& Indemnity (PEI) Insurance. Jakarta: Salemba Humanika, 2009.

Wahyunto. Et. al. Sebaran Gambut dan Kandungan Karbon di Sumatera dan Kalimantan 2004. Bogor: Wetlands International - Indonesia Programme, 2005.

Wibisana, Andri G. Penegakan Hukum Lingkungan Melalui Pertanggungjawaban Perdata. ed. 1, cet. 1. Depok: Badan Penerbit Fakultas Hukum Universitas Indonesia, 2017.

Yoe, Charles. Primer on Risk Analysis Decision Making Under Uncertainity. Boca Raton: CRC Press, 2012.

\section{Artikel Jurnal}

Faure, Michael dan Liu Jing. "Risk-Sharing Agreement to Cover Environmental Damage: Theory and Practice." International Environmental Agreements: Politics, Law and Economics Vol. 18 (2018). Hlm. 255 - 273.

Meehan, Taylor. "Lesson from The Price-Anderson Nuclear Industry Indemnity Act for Future Clean Energy Compensatory Models." Conneticut Insurance Law Journal Vol. 18.1 (2011). Hlm. 339 - 371.

Shavel, S. "The Judgement Proof Problem," International Review of Law and
Economics (1986). Hlm. 45 - 58.

Wibisana, Andri G., “Tentang Ekor yang Tak Lagi Beracun: Kritik Konseptual atas Sanksi Administratif dalam $\mathrm{Hu}-$ kum Lingkungan di Indonesia." Dalam Jurnal Hukum Lingkungan Indonesia. Vol. 6, No. 1, (Oktober 2019). Hlm. 41 - 71 .

Wibisana, Andri G. dan Pramita K. Putri. "Analisa Law and Economics atas Kompensasi dan Asuransi Lingkungan di Indonesia: Sebuah Kritik Atas Kompensasi Tanpa Sistem." Dalam Jurnal Hukum dan Pembangunan. Tahun ke-39, No.4 (Oktoher-Desember 2009). Hlm. 531 - 571.

\section{Sumber Lain}

Cambridge Dictionary. "Ex Ante." https://dictionary.cambridge.org/dictionary/english/ex-ante Diakses pada 2 April 2020.

Gabungan Pengusaha Kelapa Sawit Indonesia. "Sejarah GAPKI." https:// gapki.id/introduction Diakses 13 Juni 2019.

International Group of P\&I Clubs. "2019/20 Pool and GXL Reinsurance Contract Structure." https://www.igpandi.org/reinsurance Diakses 11 Juni 2019.

Jones, Richard. "The Price-Anderson Act." https://inis.iaea.org/collection / NCLCollectionStore/_Public/31/051/31051426.pdf Diakses pada 10 Maret 2020.

Kementerian Lingkungan Hidup dan Kehutanan. "Pencegahan Karhutla Berhasil Tekan Angka Deforestasi." 
http://www.menlhk.go.id/siaran-81-pencegahan-karhutla-berhasil-tekan-angka-deforestasi.html Diakses 16 Oktober 2018.

"Rekapitulasi Luas Kebakaran Hutan dan Lahan (Ha) per Provinsi di Tahun 2013 - 2018." http:// sipongi.menlhk.go.id/hotspot/luas_ kebakaran. Diakses pada 28 Februari 2019.

"Rekapitulasi Luas Kebakaran Hutan dan Lahan (Ha) Per Provinsi Di Indonesia Tahun 2014-2019," http://sipongi.menlhk.go.id/hotspot/luas_kebakaran diakses pada 9 Maret 2020

Out Sourcing Law Global, "Risk sharing agreement," http://www.outsourcing-law.com/risk-sharing-agreements/, diakses pada 13 Maret 2019.

Pengadilan Negeri Bandung. Putusan Nomor 49/PDT.G/2003/PN.Bdg tentang Gugatan Dedi, dkk Melawan Diresi Perum Perhutani.

Pengadilan Negeri Meulaboh. Putusan Nomor 12/PDT.G/2012/PN.MBO tentang Gugatan Menteri Lingkungan Hidup Melawan PT Kallista Alam.

Pengadilan Negeri Jakarta Utara. Putusan Nomor 108/Pdt.G/2015/PN.Jkt. Utr. tentang Gugatan Menteri Lingkungan Hidup dan Kehutanan Melawan PT Jatim Jaya Perkasa.
Pengadilan Negeri Jakarta Selatan. Putusan Nomor 591/Pdt.G-LH/2015/ PN JKT.SEL tentang Gugatan Menteri Lingkungan Hidup dan Kehutanan melawan PT National Sago Prima.

Pengadilan Tinggi Palembang. Putusan Nomor 51/PDT/2016/PT.PLG tentang Gugatan Banding Menteri Lingkungan Hidup dan Kehutanan melawan PT Bumi Mekar Hijau.

The Comprehensive Environmental Response, Compensation, and Liability Act (CERCLA).

The Law Dictionary. "What is Pool." https://thelawdictionary.org/pool/. Diakses 19 Oktober 2018.

The Oil Pollution Act (OPA).

United States Nuclear Regulatory Commission. "Backgrounder on the Three Miles Island Accident." https://www. nrc.gov/reading-rm/doc-collections/fact-sheets/nuclear-insurance. html\#require. Diakses pada 10 Juni 2019.

World Nuclear Association. "Three Miles Island Accident." http://www.world-nuclear.org/information-library/ safety-and-security/safety-of-plants/three-mile- island-accident.aspx. Diakses 10 Juni 2019. 